\title{
Detection of a parasitic amoeba (Order Dactylopodida) in the female gonads of oysters in Brazil
}

\author{
Simone Sühnel ${ }^{1,2, *}$, Celene da S. Ivachuk ${ }^{1}$, Ana L. C. Schaefer ${ }^{1}$, Vitor A. Pontinha ${ }^{1}$, \\ Maurício L. Martins ${ }^{1}$, Antonio Figueras ${ }^{3}$, Gary R. Meyer ${ }^{4}$, Simon R. M. Jones ${ }^{4}$, \\ Johnson C. Stewart ${ }^{4}$, Helen J. Gurney-Smith ${ }^{2}$, Aimê R. M. Magalhães ${ }^{1}$, \\ Susan M. Bower ${ }^{4}$ \\ ${ }^{1}$ Nucleus for Aquatic Pathology Studies, Federal University of Santa Catarina (UFSC), Rodovia Admar Gonzaga, 1346, \\ 88040-900, Florianópolis, Santa Catarina (SC), Brazil \\ ${ }^{2}$ Centre for Shellfish Research, Vancouver Island University, 900 Fifth Street, Nanaimo, British Columbia V9R 5S5, Canada \\ ${ }^{3}$ Spanish National Reference Laboratory for Molluscs Diseases, Instituto de Investigaciones Marinas, \\ Consejo Superior de Investigaciones Científicas (CSIC), Eduardo Cabello 6, 36208 Vigo, Spain \\ ${ }^{4}$ Pacific Biologic Station, Fisheries and Oceans Canada (DFO), 3190 Hammond Bay Road, Nanaimo, \\ British Columbia V9T 6N7, Canada
}

\begin{abstract}
The impacts of oocyte parasites on the reproductive success of molluscs are largely unknown. In this study, we evaluated the presence of gonad parasites in 6 species of marine bivalve molluscs native to southern Brazil. Cultured bivalves included the mangrove oyster Crassostrea gasar (sometimes called C. brasiliana), the brown mussel Perna perna, the lion's paw scallop Nodipecten nodosus and the wing pearl oyster Pteria hirundo. Another species of mangrove oyster, C. rhizophorae, and the carib pointed venus clam Anomalocardia brasiliana (syn. A. flexuosa) were collected from the wild. Molluscs were collected in winter 2009 and summer 2010 for histopathological and molecular evaluation. An unknown ovarian parasite (UOP) was observed in histopathological sections of female gonads of $C$. gasar and C. rhizophorae. The UOP possessed features suggestive of amoebae, including an irregular outer membrane, frothy cytoplasm, a nucleus with a prominent central nucleolus and a closely associated basophilic parasome. PCR analysis was negative for Marteilioides chungmuensis, Perkinsus spp. and Paramoeba perurans. However, real-time PCR successfully amplified DNA from oyster gonads when using universal Paramoeba spp. primers. Also, conventional PCR amplified DNA using primers specific for Perkinsela amoebae-like organisms (syn. Perkinsiella), which are considered as endosymbionts of Parameoba spp., previously thought to be the parasome. Our results suggest that this UOP is a species of amoeba belonging to 1 of the 2 families of the order Dactylopodida, possibly related to Paramoeba spp. This study represents the first report of this type of organism in oysters. We found that $C$. gasar and C. rhizophorae were the most susceptible molluscs to these UOPs.
\end{abstract}

KEY WORDS: Oocytes · Ovarian parasite $\cdot$ Marine bivalve $\cdot$ Amoeba

\section{INTRODUCTION}

Harvesting bivalve molluscs is important for the economy and quality of life in coastal communities of Brazil. Currently, 1 introduced species (the Pacific oyster Crassostrea gigas), and 2 native species (the brown mussel Perna perna and the lion's paw scallop Nodipecten nodosus) are farmed commercially in Brazil. Moreover, 2 native species are targeted for future cultivation: the mangrove oyster $C$. gasar and wing pearl oyster Pteria hirundo. In addition, native species of importance to commercial fisheries include 
the carib pointed venus clam Anomalocardia brasiliana and another species of mangrove oyster, C. rhizophorae. During surveys of these and other bivalves for pathogens and parasites, ovarian parasites were detected in some bivalves. Matos et al. (2005) reported Steinhausia mytilovum in oocytes of the mussel Mytella guyanensis from the Amazon River estuary, and Da Silva et al. (2012) found Steinhausia-like microsporidia in the oocytes of the clam A. brasiliana from Santa Catarina State. In oysters, Steinhausialike parasites were reported in the oocytes of C. rhizophorae from Todos os Santos Bay (Nascimento et al. 1986) and from Ceará (Sabry et al. 2013) and in C. rhizophorae and C. gigas from Santa Catarina Island, Brazil (Pontinha 2009, Sabry et al. 2011, Da Silva et al. 2012). An unusual protistan parasite was reported in oocytes of some oysters from southern Brazil (Da Silva et al. 2012, Ivachuk 2013).

Steinhausia spp. (Kingdom Fungi, Phylum Microsporidia) are characterized by spheroid sporocysts (9-18 $\mu \mathrm{m}$ in diameter) that contain numerous spherical developing spores (about 1-3 $\mu \mathrm{m}$ in diameter). Sporocysts occur in parasitophorous vacuoles, delimited by a thin membrane, within the cytoplasm or nucleus of the host oocyte (Sagristà et al. 1998). These parasites have a global distribution and have been reported from the oocytes of mussels, cockles, clams and oysters (Comtet et al. 2003, Green et al. 2008).

Another parasite that infects the oocytes of bivalves is Marteilioides chungmuensis (Kingdom Chromista, Phylum Cercozoa but initially placed in the Phylum Paramyxea; Berthe et al. 2000). M. chungmuensis is characterized by 1 to 3 (usually 2) secondary cells (sporonts) in the remnants of the stem cell within the oocyte of its host. Each sporont contains 1 tertiary cell that develops into a tricellular spore by internal cleavage (Itoh et al. 2004a). This parasite can affect oocytes in large areas of the reproductive follicles, which causes irregular enlargement of the infected gonadal tissues, giving the infected oyster a nodular appearance suggestive of multiple tumours. Originally described in C. gigas from Korea (Comps et al. 1987), it also occurs in C. gigas and C. nippona from Japan (Itoh et al. 2004b), and a similar parasite was reported from the ova of $C$. echinata from Australia (Hine \& Thorne 2000). A Marteilioides-like parasite was also reported at low prevalence $(1.6 \%)$ from the oocytes of Manila clams Venerupis (=Tapes) philippinarum, in coastal areas of Korea (Lee et al. 2001).

In addition to the unidentified ovarian parasites reported from Santa Catarina Island, Brazil (Da Silva et al. 2012, Ivachuk 2013), Becker \& Pauley (1968) detected an unusual parasite in the oocytes of
C. gigas from Humboldt Bay, California, USA. In British Columbia, Canada, a similar unidentified ovarian parasite was encountered in a C. gigas specimen (G. R. Meyer \& S. M. Bower unpubl.; further details provided in the [Discussion] section).

During recent histopathological surveys (2009 and 2010) of commercially important bivalves from southern Brazil, a protistan parasite was detected in the oocytes of ripe female oysters. The morphology of this parasite differed from that of Steinhausia spp. and $M$. chungmuensis, and the prevalence of this unidentified ovarian parasite in some oyster populations in Brazil was high. Concern about the potential impact of this parasite on bivalve production in Brazil prompted investigations into the identity of the parasite including reassessment of all bivalves included in the recent surveys for the presence of this parasite.

\section{MATERIALS AND METHODS}

\section{Sampling and location}

To evaluate the presence or absence of the oocyte parasites in cultured and wild bivalve molluscs from Santa Catarina State (SC), southern Brazil, a total of 480 bivalves collected in winter (August/2009) and summer (January/2010) were examined histologically (Table 1).

Specimens belonging to 4 species of cultured bivalves were obtained. Mangrove oysters Crassostrea gasar, brown mussels Perna perna and wing pearl oysters Pteria hirundo were sampled from culture systems within the experimental area of the Federal University of Santa Catarina (UFSC), Ponta do Sambaqui beach $\left(27^{\circ} 29^{\prime} 18.8^{\prime \prime} \mathrm{S}, 48^{\circ} 32^{\prime} 12.9^{\prime \prime} \mathrm{W}\right)$, Florianópolis, SC. The lion's paw scallops Nodipecten nodosus were from lantern-net cultures at the experimental area of Empresa de Pesquisa Agropecuária e Extensão Rural de Santa Catarina (Company of Agricultural Research and Rural Extension of Santa Catarina), located on Bombinhas beach $\left(27^{\circ} 12^{\prime} 5.4^{\prime \prime} \mathrm{S}, 48^{\circ} 30^{\prime} 47.7^{\prime \prime} \mathrm{W}\right)$, Bombinhas, SC.

Two species of wild molluscs were randomly selected from intertidal areas in Florianópolis (SC). The mangrove oysters $C$. rhizophorae were from a rocky shore site (approximately $100 \mathrm{~m}^{2}$ ) at Ponta do Sambaqui beach $\left(27^{\circ} 29^{\prime} 26.5^{\prime \prime} \mathrm{S}, \quad 48^{\circ} 32^{\prime} 17.9^{\prime \prime} \mathrm{W}\right)$, and the carib pointed venus clams Anomalocardia brasiliana were from another site (approximately $200 \mathrm{~m}^{2}$ ) within the Reserva Marinha Extrativista do Pirajubaé-REMAPI (Marine Extractive Reserve of Pirajubaé; $27^{\circ} 29^{\prime} 18.8^{\prime \prime}$ S, $48^{\circ} 32^{\prime} 12.9^{\prime \prime} \mathrm{W}$ ). 
Table 1. Details pertaining to the female bivalve molluscs from Santa Catarina State, Brazil, that were examined by histology: wing pearl oyster Pteria hirundo, mussel Perna perna, oysters Crassostrea gasar and C. rhizophorae, scallop Nodipecten nodosus and clam Anomalocardia brasiliana. Length is mean ( $\pm \mathrm{SD})$ shell length for all individuals in a sample. Note that the species N. nodosus is a simultaneous hermaphrodite. The stages of gonadal development are gametogenesis (GA), pre-spawning (PS), spawning (SP) and resting (RE). Unk.: Unknown

\begin{tabular}{|c|c|c|c|c|c|c|c|c|c|c|c|c|}
\hline \multirow[t]{2}{*}{ Species } & \multirow[t]{2}{*}{$\begin{array}{l}\text { Sampling } \\
\text { season }\end{array}$} & \multirow[t]{2}{*}{$\begin{array}{c}\text { Age } \\
\text { (yr) }\end{array}$} & \multirow[t]{2}{*}{$\begin{array}{c}\text { Length } \\
(\mathrm{mm})\end{array}$} & \multirow{2}{*}{$\begin{array}{l}\text { No. of } \\
\text { females } \\
\text { (total) }\end{array}$} & \multicolumn{4}{|c|}{$\begin{array}{c}\text { Female gonad stage } \\
\text { (\% ind.) }\end{array}$} & \multicolumn{4}{|c|}{$\begin{array}{l}\text { Parasitized females } \\
\text { (n) }\end{array}$} \\
\hline & & & & & GA & PS & $\mathrm{SP}$ & $\mathrm{RE}$ & GA & PS & $\mathrm{SP}$ & $\mathrm{RE}$ \\
\hline \multicolumn{13}{|l|}{ From culture } \\
\hline P. hirundo & Summer 2010 & 3 & $60.18 \pm 1.60$ & $12(30)$ & 0 & 91.7 & 8.3 & 0 & - & 0 & 0 & - \\
\hline \multirow[t]{2}{*}{ P. perna } & Winter 2009 & 1 & $71.11 \pm 4.03$ & $18(40)$ & 38.9 & 11.1 & 11.1 & 38.9 & 0 & 0 & 0 & 0 \\
\hline & Summer 2010 & 1 & $70.53 \pm 3.63$ & $11(40)$ & 0 & 0 & 90.9 & 9.1 & - & - & 0 & 0 \\
\hline \multirow[t]{2}{*}{ C. gasar } & Winter 2009 & 1 & $52.01 \pm 8.35$ & $3(40)$ & 0 & 0 & 0 & 100 & - & - & - & 0 \\
\hline & Summer 2010 & 1 & $52.67 \pm 4.52$ & $19(40)$ & 0 & 0 & 100 & 0 & - & - & 19 & - \\
\hline \multirow[t]{2}{*}{ N. nodosus } & Winter 2009 & 1.5 & $67.08 \pm 5.70$ & $40(40)$ & 2.5 & 35.0 & 47.5 & 15.0 & 0 & 0 & 0 & 0 \\
\hline & Summer 2010 & 1.5 & $66.42 \pm 3.85$ & $40(40)$ & 45.0 & 52.5 & 0.0 & 2.5 & 0 & 0 & 0 & 0 \\
\hline \multicolumn{13}{|l|}{ From wild } \\
\hline \multirow[t]{2}{*}{ C. rhizophorae } & Winter 2009 & Unk. & $60.55 \pm 7.90$ & $24(40)$ & 4.2 & 8.3 & 62.5 & 25.0 & 0 & 1 & 15 & 0 \\
\hline & Summer 2010 & Unk. & $61.34 \pm 4.54$ & $23(40)$ & 4.3 & 87.0 & 8.7 & 0 & 0 & 2 & 2 & - \\
\hline \multirow[t]{2}{*}{ A. brasiliana } & Winter 2009 & Unk. & $21.63 \pm 4.29$ & $17(40)$ & 0 & 0 & 0 & 100 & - & - & - & 0 \\
\hline & Summer 2010 & Unk. & $22.43 \pm 2.31$ & $16(40)$ & 0 & 0 & 87.5 & 12.5 & - & - & 0 & 0 \\
\hline
\end{tabular}

During sampling, visual assessments for mortality at each site were made. Bivalves were transported on ice to the Nucleus for Aquatic Pathology Studies laboratory of UFSC, for dissection within $2 \mathrm{~h}$ of collection. The maximum shell length (hinge to bill) was recorded, and each bivalve was dissected using sterile techniques. During the dissection, the following macroscopic features were recorded: colouration of the gills, digestive gland, mantle and gonad; presence of nodules in the digestive gland, mantle and gonad; and appearance of the valves.

\section{Histology}

Cross sections and/or pieces of tissue about $1 \mathrm{~cm}$ thick that represented all major organs were fixed for 48 h in Davidson's fixative (Shaw \& Battle 1957), then dehydrated and embedded in paraffin. Histological sections (5 $\mu \mathrm{m}$ thick) were stained with haematoxylin-eosin (H\&E) and examined using light microscopy. The entire gonadal area of each bivalve within each histological section was examined under 100, 400 and $1000 \times$ magnification. The sex, stage of gonadal development (gametogenesis, pre-spawning [ripe], spawning and resting [spent]), the presence of haemocyte infiltration and occurrence of oocyte parasites were recorded for each specimen. Prevalence was calculated according to Bush et al. (1997), and the intensity of infection was calculated by stereological analysis using a Weibel graticule with 21 short lines and 2 account-points in each extremity (42 account-points in total; Weibel et al. 1966). Briefly, under 400× magnification, 5 random and non-overlapping fields were selected in the gonad area and the parasites at each account-point were counted. The size of the unknown ovarian parasite (UOP) was determined from heavily infected oysters. The greatest diameter of 25 parasites containing the nucleus and parasome in the cross-section (see Fig. 3) as well as the diameter of the nucleus and parasome were measured. In addition, parasites showing evidence of division were photographed and a proposed sequence of division assembled.

\section{DNA extraction}

A small piece of gonad tissue was dissected from 4 species (P. perna, C. gasar, N. nodosus and A. brasiliana that were examined by histology) using sterile techniques and preserved in $95 \%$ undenatured ethanol at $4{ }^{\circ} \mathrm{C}$. DNA was extracted from the samples using a DNeasy Blood \& Tissue Kit (Qiagen) following the manufacturer's instructions. DNA concentration and purity were measured using a NanoVue® spectrophotometer.

\section{PCR}

Some morphological features of the UOP were generally similar to those of Paramoeba (syn. Neoparamoeba, according to Feehan et al. 2013) spp., 
Perkinsus spp. and Marteilioides spp. Molecular probes were therefore used to detect parasites in these genera as well as endosymbionts or parasomes of Paramoeba spp. (genus Perkinsela). Table 2 lists the oligonucleotide primers and probe used to specifically amplify parasite DNA by conventional and real-time PCR. The negative control was nucleasefree water. Assay details pertaining to each parasite are as follows.

\section{Paramoeba spp.}

The real-time PCR was performed on DNA samples from the gonad of 6 heavily infected C. gasar according to Fringuelli et al. (2012), using the primer set for the 18S rRNA gene of Paramoeba spp. (UN for, UN rev and UN probe as described in Table 2). The reaction mixture included $10 \mu \mathrm{l}$ of Sybr Green Kappa (Applied Biosystems), $0.6 \mu \mathrm{M}$ of forward and $0.9 \mu \mathrm{M}$ of reverse primers, $0.1 \mu \mathrm{M}$ of probe and $2 \mu \mathrm{l}$ of DNA template at a concentration of $100 \mathrm{ng} \mathrm{Hl}^{-1}$ in a total volume of $20 \mu \mathrm{l}$. The real-time PCR was carried out using a 7900HT Real-Time PCR System (Applied Biosystems) under the following conditions: (1) pre-denaturation at $95^{\circ} \mathrm{C}$ for $15 \mathrm{~min}$ and (2) 45 amplification cycles of denaturation at $95^{\circ} \mathrm{C}$ for $15 \mathrm{~s}$ and annealing/extension at $56^{\circ} \mathrm{C}$ for $30 \mathrm{~s}$ each. Fluorescence in the VIC channel was obtained during the annealing/extension stage. The positive control for the Paramoeba spp. assays was a DNA solution extracted from the gill of Atlantic salmon infected with P. perurans.

The conventional PCR was performed on DNA samples from the gonad of the same 6 heavily infected C. gasar to test for the presence of $P$. perurans. The PCR was performed according to Young et al. (2008) with modifications to the amplification conditions. The primer set used was N.perurF and N.perurR (Table 2). The PCR reaction with a total volume of $25 \mu \mathrm{l}$ was made up of $20 \mu \mathrm{l}$ of PCR SuperMix, $1 \mu \mathrm{l}$ of each primer, $1 \mu \mathrm{l}$ of $\mathrm{dd}_{2} \mathrm{O}$ and $2 \mu \mathrm{l}$ of DNA template at a concentration of $100 \mathrm{ng} \mathrm{pl}^{-1}$. The amplification conditions were as follows: (1) initial

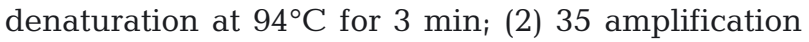
cycles of $94^{\circ} \mathrm{C}$ for $45 \mathrm{~s}, 50^{\circ} \mathrm{C}$ for $45 \mathrm{~s}$ and $72^{\circ} \mathrm{C}$ for $90 \mathrm{~s}$; and (3) final elongation at $72^{\circ} \mathrm{C}$ for $10 \mathrm{~min}$. The same positive control used in the real-time PCR assay for Paramoeba spp. was employed. The PCR products were run on a $1 \%$ agarose gel ( $100 \mathrm{~V}$ for $40 \mathrm{~min})$ and the presence or absence of amplified DNA of the expected product size for $P$. perurans (Table 2) was assessed by comparison to product obtained for the positive control.

\section{Endosymbiont of Paramoeba spp.}

Endosymbiont-specific PCR was performed according to Dyková et al. (2008) with modifications to the amplification conditions as indicated below. The primer set used was PERK-F and PERK-R (Table 2).

Table 2. Primer sequences for conventional PCR to evaluate the presence or absence of Marteilioides chungmuensis, Perkinsus spp., Paramoeba (syn. Neoparamoeba) perurans and Perkinsela amoebae-like organism, and for real-time PCR to evaluate the presence or absence of Paramoeba spp. F: forward; R: reverse

\begin{tabular}{|c|c|c|c|c|c|}
\hline Target parasite & $\begin{array}{l}\text { Primer } \\
\text { name }\end{array}$ & Sequence $\left(5^{\prime}-3^{\prime}\right)$ & Dir. & $\begin{array}{l}\text { Product } \\
\text { size (bp) }\end{array}$ & Reference \\
\hline \multicolumn{6}{|l|}{ Real-time PCR } \\
\hline \multirow[t]{3}{*}{ Paramoeba spp. } & UN for & CGA TCA GAT ACC GTC GTA GTC & $\mathrm{F}$ & 150 & Fringuelli et al. (2012) \\
\hline & UN rev & CAG CCT TGC GAC CAT ACT C & $\mathrm{R}$ & & \\
\hline & UN probe & VIC-CTC CTT CAG TAC CTT ACG AG & & & \\
\hline \multicolumn{6}{|l|}{ Conventional PCR } \\
\hline \multirow{2}{*}{$\begin{array}{l}\text { Paramoeba } \\
\text { perurans }\end{array}$} & N.perurF & ATC TTG ACY GGT TCT TTC GRG A & $\mathrm{F}$ & 636 & Young et al. (2008) \\
\hline & N.perurR & ATA GGT CTG CTT ATC ACT YAT TCT & $\mathrm{R}$ & & \\
\hline \multirow{2}{*}{$\begin{array}{l}\text { Perkinsela amoebae- } \\
\text { like organism }\end{array}$} & PERK-F & GGA TAA CTT CGC GAA ACG CGA & F & 1365 & Dyková et al. (2008) \\
\hline & PERK-R & GCT TTG ATG AAG CAC GTC TAC & $\mathrm{R}$ & & \\
\hline \multirow[t]{2}{*}{ Perkinsus spp. } & PerkITS-85 & CCG CTT TGT TTG GAT CCC & $\mathrm{F}$ & 703 & Audemard et al. (2004) \\
\hline & PerkITS-750 & ACA TCA GGC CTT CTA ATG ATG & $\mathrm{R}$ & & \\
\hline \multirow{4}{*}{$\begin{array}{l}\text { Marteilioides } \\
\text { chungmuensis }\end{array}$} & OPF-2 & CCG CGT TTA CAC CTG TGA CC & F & 672 & Itoh et al. (2003) \\
\hline & OPR-2 & GAC CTT CCG ATT ATC CGC CC & $\mathrm{R}$ & & \\
\hline & OPF-3 & GGC TGA ATA CCT CTG CC & $\mathrm{F}$ & 447 & \\
\hline & OPR-3 & CCT CTT GAC GAC GAC AC & $\mathrm{R}$ & & \\
\hline
\end{tabular}


The PCR reaction (total volume of $25 \mu \mathrm{l}$ ) was made up of $20 \mu \mathrm{l}$ of PCR SuperMix, $1 \mu \mathrm{l}$ of each primer, $1 \mu \mathrm{l}$ of $\mathrm{ddH}_{2} \mathrm{O}$ and $2 \mu \mathrm{l}$ of DNA template at a concentration of $100 \mathrm{ng} \mathrm{Hl}^{-1}$. The amplification conditions were as follows: (1) initial denaturation at $95^{\circ} \mathrm{C}$ for $3 \mathrm{~min}$; (2) 35 amplification cycles of $94^{\circ} \mathrm{C}$ for $45 \mathrm{~s}, 60^{\circ} \mathrm{C}$ for $45 \mathrm{~s}$ and $72^{\circ} \mathrm{C}$ for $2 \mathrm{~min}$; and (3) final elongation at $72^{\circ} \mathrm{C}$ for $10 \mathrm{~min}$. The positive control was genomic DNA extracted from Atlantic salmon gills infected with $P$. perurans and previously shown by PCR to be positive for Perkinsela amoebae-like organisms. The PCR products were run on a $1 \%$ agarose gel $(100 \mathrm{~V}$ for $40 \mathrm{~min})$, and the presence or absence of amplified DNA of the expected product size for $P$. amoebae (Table 2) was assessed by comparison to the product obtained for the positive control.

\section{Perkinsus spp.}

DNA samples from the gonads $(n=6)$ and a mix of gills and digestive gland $(\mathrm{n}=1)$ from heavily infected C. gasar were assayed by PCR according to Audemard et al. (2004) and OIE (2013), using the primers PerkITS-85 and PerkITS-750 (Table 2). The PCR reaction included $45 \mu \mathrm{l}$ of PCR SuperMix, $1 \mu$ of each primer, $1 \mu \mathrm{l}$ of $\mathrm{ddH}_{2} \mathrm{O}$ and $2 \mu \mathrm{l}$ of DNA template at a concentration of $100 \mathrm{ng} \mathrm{\mu l}^{-1}$, in a total volume of $50 \mu$. The amplification was carried under the following conditions: (1) initial denaturation at $95^{\circ} \mathrm{C}$ for $4 \mathrm{~min}$; (2) 40 amplification cycles of $95^{\circ} \mathrm{C}$ for $1 \mathrm{~min}$, $55^{\circ} \mathrm{C}$ for $1 \mathrm{~min}$ and $65^{\circ} \mathrm{C}$ for $3 \mathrm{~min}$; and (3) final elongation at $65^{\circ} \mathrm{C}$ for $5 \mathrm{~min}$. The PCR products were run on a $1.5 \%$ agarose gel (100 V for $40 \mathrm{~min})$, and the presence or absence of amplified DNA of the expected product size (703 bp) was assessed by comparison to products obtained for positive controls of Perkinsus marinus and $P$. olseni (extracted DNA suspension, provided by G. Lowe, Pacific Biological Station, Canada).

\section{Marteilioides chungmuensis}

A nested PCR was performed according to Itoh et al. (2003), on DNA from gonad samples of $P$. perna (n = 2), C. gasar infected with the UOP ( $\mathrm{n}=2$ ), $N$. nodosus $(\mathrm{n}=2)$ and $A$. brasiliana $(\mathrm{n}=2)$ using a first-round primer set OPF-2/OPR-2 and a secondround PCR primer set OPF-3/OPR-3 (Table 2). Both PCR reactions included $45 \mu$ of PCR SuperMix (Applied Biosystems), $1 \mu \mathrm{l}$ of each primer, $1 \mu \mathrm{l}$ of $\mathrm{ddH}_{2} \mathrm{O}$ and $2 \mu \mathrm{l}$ of DNA template at a concentration of $100 \mathrm{ng} \mathrm{ul}^{-1}$, using a Mastercycler gradient (Eppendorf) in a total volume of $50 \mu \mathrm{l}$. The first-round PCR amplification was carried out as follows: (1) initial denaturation at $94^{\circ} \mathrm{C}$ for $5 \mathrm{~min}$; (2) 35 amplification cycles of $94^{\circ} \mathrm{C}$ for $1 \mathrm{~min}, 59^{\circ} \mathrm{C}$ for $30 \mathrm{~s}$, and $72^{\circ} \mathrm{C}$ for $1 \mathrm{~min}$; and (3) final elongation at $72^{\circ} \mathrm{C}$ for $10 \mathrm{~min}$. The second-round PCR used the same thermocycling conditions, with the exception of an amplification annealing temperature of $55^{\circ} \mathrm{C}$ rather than $59^{\circ} \mathrm{C}$. The electrophoresis was performed using a Bioanalyzer DNA Chips Agilent 2100 (Agilent Technologies), according to the manufacturer's instructions. The presence of amplified DNA of the expected product size in the first PCR (672 bp) and in the second PCR (447 bp) was assessed by comparison to products obtained for positive controls for $M$. chungmuensisinfected oyster DNA (extracted DNA suspension, provided by G. Lowe, Pacific Biological Station, Canada).

\section{RESULTS}

\section{Histological analysis of bivalve gonad tissue}

The UOP was only observed in females of Crassostrea gasar and C. rhizophorae (Table 1). The parasite was only detected in the gonads of oysters at spawning and pre-spawning stages of gonadal development. In samples of wild C. rhizophorae collected in winter 2009, the UOP was observed in all 15 spawning and in 1 pre-spawning female, but not in the remaining 8 females (overall prevalence $=67 \%$ ). In summer 2010, infections were observed in $2 / 2$ spawning and in 2/20 pre-spawning females, but not in the remaining females undergoing gametogenesis (overall prevalence $=17 \%$ ). In samples of cultured C. gasar collected in summer 2010, the UOP was detected in all 19 spawning females (100\%). The parasite was not detected in a sample of 3 females collected from this site in winter 2009; however, the sex could not be determined in over $90 \%$ of the 40 oysters sampled, and all were at the resting stage of gonadal development (Table 1). The mean intensity of oocyte infection for C. rhizophorae was similar in the winter and summer samples $(2.14 \pm 0.61 \%$ and $2.21 \pm 1.65 \%$, respectively, of the oocytes infected). Oocyte infection intensity was greater in C. gasar summer samples, where $5.38 \pm 2.96 \%$ of the oocytes were infected.

No alterations were observed macroscopically in infected animals, and no oyster mortality was observed during the oyster sampling. However, his- 
tologically, all parasitized C. gasar and C. rhizophorae showed intense haemocytic infiltration in the vicinity of the parasitized oocytes (Figs. 1 \& 2). Also, the epithelial layers of the gonadal follicles containing infected oocytes were severely disrupted (Fig. 2). No evidence of destruction or impairment of tissues was observed beyond the foci of infection (Fig. 1). No UOPs were found in the other organs, including the mantle, gills, adductor muscle and digestive gland. However, a few UOPs were observed among haemocytes in the connective tissue between the gonad and the digestive gland.

The parasite was spheroid in shape with an irregular outer membrane. The cytoplasm appeared frothy and contained numerous vacuoles of various sizes and a nucleus with a prominent central nucleolus. A basophilic parasome usually with peripheral chromatin was located near the nucleus (Fig. 3). In C. gasar, the mean \pm SD diameter of the UOP $(\mathrm{n}=25)$ was $6.57 \pm 0.73 \mu \mathrm{m}$, the diameter of the nucleus was $1.96 \pm 0.34 \mu \mathrm{m}$, and the diameter of the parasome was $1.88 \pm 0.36 \mu \mathrm{m}$. These measurements were similar in C. rhizophorae $(\mathrm{n}=25): 6.03 \pm 0.55,1.69 \pm 0.25$ and $1.68 \pm 0.33 \mu \mathrm{m}$, respectively. In some UOPs, a large central vacuole displaced the nucleus to the periphery of the cell (Fig. 4).

Most infected oocytes contained 1 UOP, usually within the cytoplasm and occasionally in the nucleus. However, in heavily infected oysters, several UOPs (up to 10) were observed in 1 oocyte. The histological staining of the cytoplasm in a few heavily infected oocytes was altered (Fig. 5). The parasite appeared to disrupt the nuclear membranes of its host cell (see Fig. 10). Single haemocytes were occasionally observed in the cytoplasm of infected oocytes (see Fig. 9). Some UOPs also occurred between oocytes among the haemocytes (Fig. 6). In oocytes and between haemocytes, UOPs were usu-
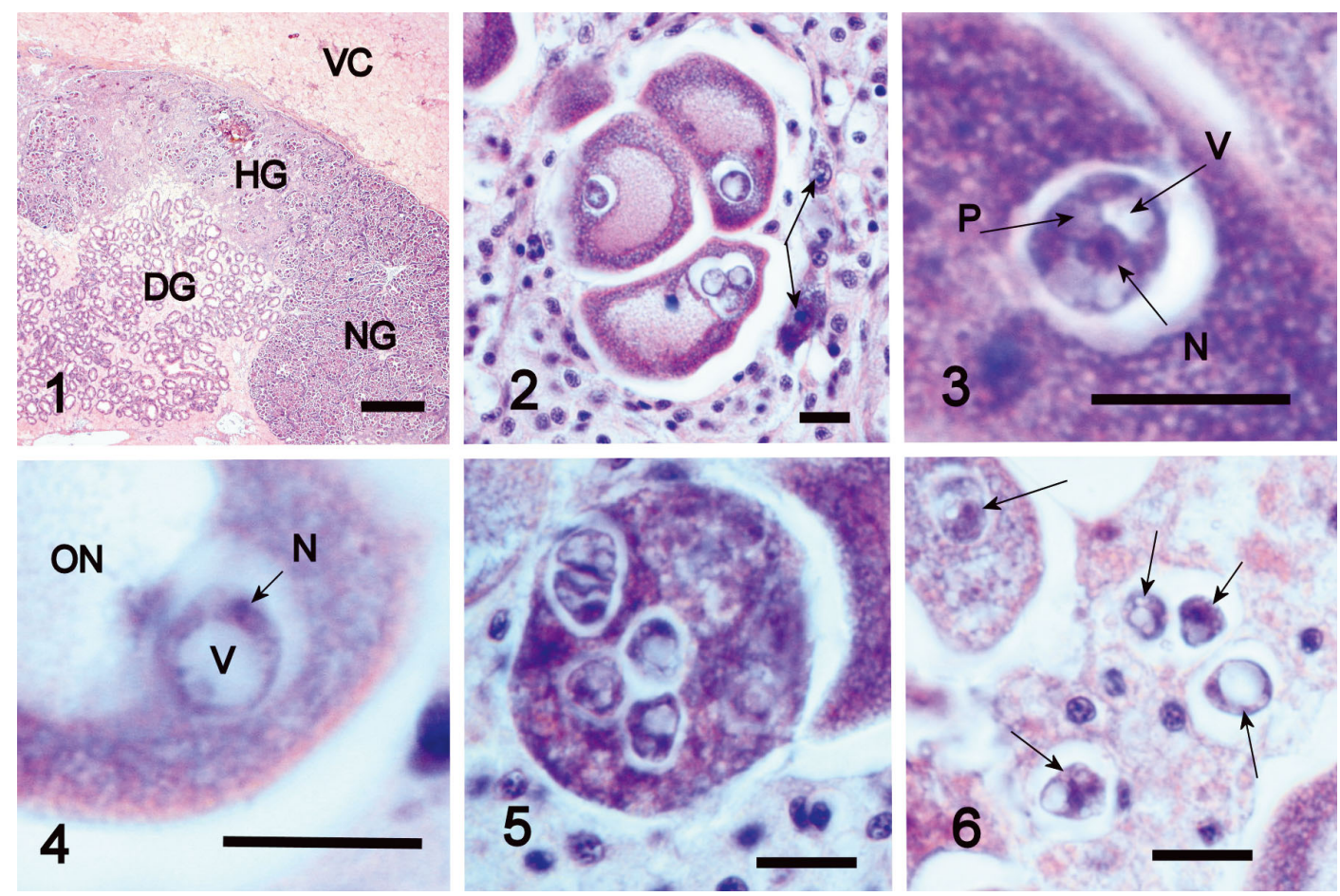

Figs. 1 to 6. Histological sections (haematoxylin and eosin stain) of parasitic amoebae (unknown ovarian parasites, UOPs) in the gonad of a mature female Crassostrea gasar from an aquaculture site at Ponta do Sambaqui beach, Florianópolis, Brazil. Fig. 1. Low magnification of a cross-section through an infected oyster with significant histopathology in the infected area of the gonad (HG) in contrast to normal gonadal tissue (NG) and no evidence of pathology in surrounding vesicular connective tissues (VC) and adjacent digestive gland (DG). Fig. 2. Cluster of 3 infected oocytes surrounded by haemocytes with few remnant cells from the gonadal follicle epithelium (arrows). Fig. 3. Classical amoeba profile with a nucleus (N) containing a prominent central nucleolus, a basophilic parasome (P) containing peripheral chromatin, cytoplasmic vacuoles (V) and surrounded by a vacuole-like space in the cytoplasm of an oocyte. Fig. 4. Signet ring morphology of the UOP with a large central vacuole $(\mathrm{V})$ that has displaced the nucleus $(\mathrm{N})$ to the periphery of the parasite in the cytoplasm of the host oocyte adjacent to its nucleus (ON). Fig. 5. Several UOPs in the cytoplasm of an oocyte with unusual staining properties. Fig. 6. UOPs (arrows) among the haemocytes between oocytes, 1 of which is infected (arrow upper left corner). Scale bars $=$

(Fig. 1) $500 \mu \mathrm{m}$, (Figs. 2-6) $10 \mu \mathrm{m}$ 
ally surrounded by a vacuole-like space. In most cases, 1 UOP was observed in each vacuole-like space. However, some vacuole-like spaces within the oocytes contained 2 or more UOPs, and up to 10 were counted in 1 vacuole. Dividing stages were occasionally observed within the oocytes (Figs. 7-12). Division occurred by binary fission. Nuclear division (Figs. $7 \&$ 8) was followed by migration of the resulting 2 nuclei to opposite sides of the UOP (Fig. 9). Although division of the parasome was not directly observed, by the time the nuclei were separated, a parasome was again found to be associated with each nucleus (Fig. 10). The cytoplasm cleaved (Fig. 11), and the resulting daughter cells were often observed in close proximity (Fig. 12).

\section{Real-time PCR for Paramoeba spp.}

Gonad DNA from heavily infected C. gasar had a mean cycle threshold value $\left(\mathrm{C}_{t}\right)$ of $26.6 \pm 0.17$ (range, 25.9-27.2). The mean $C_{t}$ in the no-template control was $34.1 \pm 1.25$ (range, 29.5-37.1), whereas the positive control for $P$. perurans had a mean $C_{t}$ value of $22.4 \pm 0.4$ (range, 21.9-22.9).

\section{PCR for Marteilioides chugmuensis, Perkinsus spp., Paramoeba perurans and the Paramoeba endosymbiont}

In the nested-PCR assays performed with P. perna, C. gasar, N. nodosus and A. brasiliana, no product was seen, excluding the possibility of $M$. chungmuensis infection.

DNA from gonads, gills and digestive gland of heavily infected C. gasar did not amplify in PCR assays for Perkinsus spp. Also, there was no product in the PCR assays with C. gasar for P. perurans.

The endosymbiont of Paramoeba spp. PCR product obtained from a heavily infected C. gasar was a band of the appropriate size (1365 bp). A product of the same size was produced from the positive control sample.
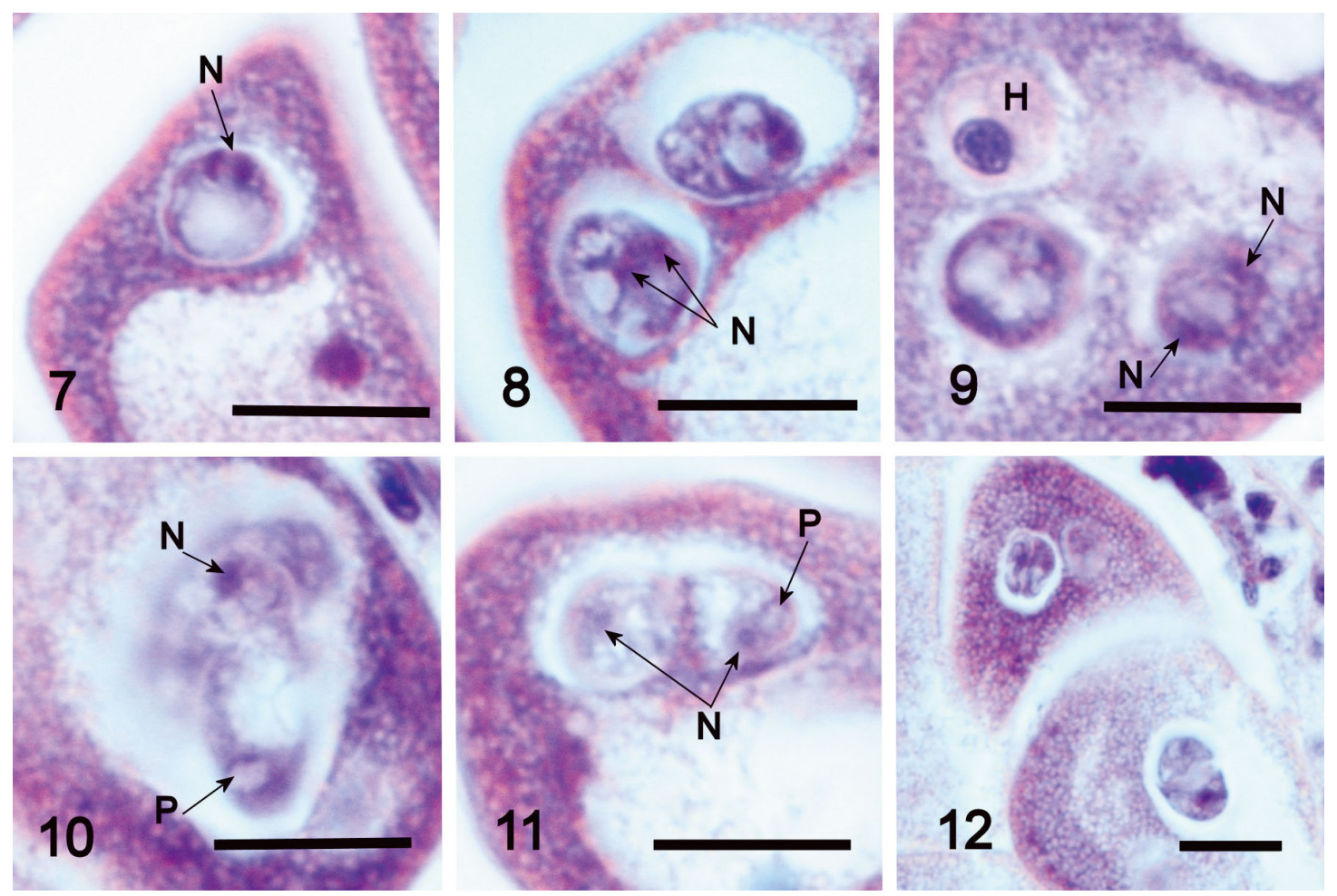

Figs. 7 to 12. Histological sections (haematoxylin and eosin stain) of dividing amoebae (unknown ovarian parasites, UOPs) in the oocytes of a ripe female Crassostrea gasar from an aquaculture site at Ponta do Sambaqui beach, Florianópolis, Brazil. Fig. 7. Nucleus (N) in anaphase stage of mitosis. Fig. 8. One (possibly both) UOP in early telophase stage of parasite division (N). Fig. 9. Nuclei $(\mathrm{N})$ have migrated to opposite sides of the UOP (note that a second UOP and a haemocyte $(\mathrm{H})$ occur in the cytoplasm of this infected oocyte). Fig. 10. Cytoplasm beginning to cleave. At this level of focus, the nucleus (N) at one pole and the parasome (P) at the other are evident; also, the host cell nucleus is degenerating (upper left corner of image). Fig. 11. Cytoplasmic cleavage nearing completion with the nucleus $(\mathrm{N})$ and parasome $(\mathrm{P})$ of 1 UOP visible. Fig. 12. Two pairs of recently divided UOPs occur in close proximity within the cytoplasm of adjacent oocytes. All scale bars $=10 \mu \mathrm{m}$ 


\section{DISCUSSION}

Morphological features and molecular assays confirmed that the parasite in the gonads of ripe female oysters in Brazil is new to science.

Parasites most commonly reported from the ova of bivalves are Steinhausia spp. However, the UOP found in the mangrove oysters Crassostrea gasar and C. rhizophorae described herein had different morphological features evident by light microscopy. Unlike Steinhausia spp., the cells of this UOP were larger and less numerous in each vacuole, and no spores were evident. Because Marteilioides chungmuensis is of considerable disease concern in areas of the North Pacific Asian coast, we excluded the possibility that the UOP was $M$. chungmuensis when no product was found in the nested-PCR analysis. Also, the UOP did not cause irregular, grossly visible enlargement of the infected gonadal tissues (nodular appearance) characteristic of oysters infected with $M$. chungmuensis, and many histological features typical of $M$. chungmuensis were not evident in the UOP. Although some UOPs had a large vacuole which displaced the nucleus to the periphery of the cell ('signet-ring' appearance), characteristic of Perkinsus marinus trophozoites (compare Fig. 9 in Perkins 1996 to Fig. 4 herein), the PCR assay for Perkinsus spp. was negative.

The irregular outline of the UOP, the frothy-looking cytoplasm, the prominent centrally located nucleolus in the nucleus and, most importantly, the presence of a parasome suggested that this UOP is related to ubiquitous members of the Order Dactylopodida and may be a species of Paramoeba or Janickina. Species in these genera are free-living amoebae in the marine environment and facultative parasites of marine vertebrates and invertebrates. The presence of the basophilic parasome in the cytoplasm of the amoeba is an important characteristic for the identification of amoebae in these genera (Page 1983). In these amoebae, the parasome is an endosymbiont related to members of the Kinetoplastida flagellates and variously referred to as Ichthyobodo necator-related organism (Caraguel et al. 2007, Tanifuji et al. 2011), Perkinsiella amoebae (Hollande 1980, Dyková et al. 2000), Perkinsiella amoebae-like endosymbiont (Dyková et al. 2003), and Perkinsela amoebae-like organism (Dyková et al. 2008, Feehan et al. 2013). As explained by Dyková et al. (2008), the senior homonym Perkinsiella is a genus of insects, thus requiring a replacement name of Perkinsela. Amplification observed in the real-time PCR for Paramoeba spp. and for the endosymbiont $P$. amoebaelike organism by conventional PCR supported this view and suggested that the UOP in the mangrove oysters C. gasar and C. rhizophorae is an amoeba belonging to the Subclass Flabellinia, Order Dactylopodida. The relatively high $\mathrm{C}_{t}$ values obtained with the Paramoeba-generic assay is likely the combined result of reduced sequence homology and relatively low abundance of target DNA in the sample. Failure of the Paramoeba perurans-specific PCR indicated that this UOP is not $P$. perurans.

Reports of similar looking parasites were described by Da Silva et al. (2012) and Ivachuk (2013). However, these authors observed lower prevalences (2.50 and $2.10 \%$, respectively) in Pacific oysters C. gigas from southern Brazil.

Interestingly, Becker \& Pauley (1968) reported a gonad parasite, with similar features to the UOP described here, in mature gonads of $C$. gigas from Humboldt Bay, California, which they called Humboldt egg parasite (HEP). Although detected at a relatively high prevalence in female oysters (15 of 21 infected), those authors observed the HEP only in the cytoplasm of the oocytes. They did not identify the taxonomic affiliation of the HEP and considered it as 'Protista Incertae Sedis'. A similar gonad parasite was also observed in a partially spawned female oyster C. gigas from Read Island, British Columbia, Canada, in November 2009 (G. R. Meyer \& S. M. Bower unpubl. report). Nucleus and parasome were evident in the oocyte parasites observed in histological sections (Fig. 13). Only this single infection has been detected in British Columbia over the past $25 \mathrm{yr}$, during which time more than 2000 mature female oysters have been examined for parasites and diseases using histology.

The haemocytic infiltration associated with the UOP observed in the present study is a typical immunological response of bivalves. A similar response was reported by Da Silva et al. (2012) and Ivachuk (2013) in the gonads of female C. gigas infected with unknown ovarian parasites.

The impact of intracellular infection in oocytes on the reproductive cycle is unknown (Comtet et al. 2004, Bower 2012). However, many authors (e.g. Bower \& Figueras 1989, Villalba et al. 1997, Comtet et al. 2004) have suggested that parasites in the oocytes may affect reproduction of infected molluscs. The parasites can distort the nucleus of the gamete and can also cause the destruction of the oocyte (Rybakov \& Kholodkovskaya 1987, Bower 2012). Also, the mollusc's fecundity is believed to be inversely related to the intensity of infection. Cunningham \& Daszak (1998) associated the extinction of snails Partula turgida on Ra'iatea (Society Islands) with a Steinhausia sp. infection. Further research is 


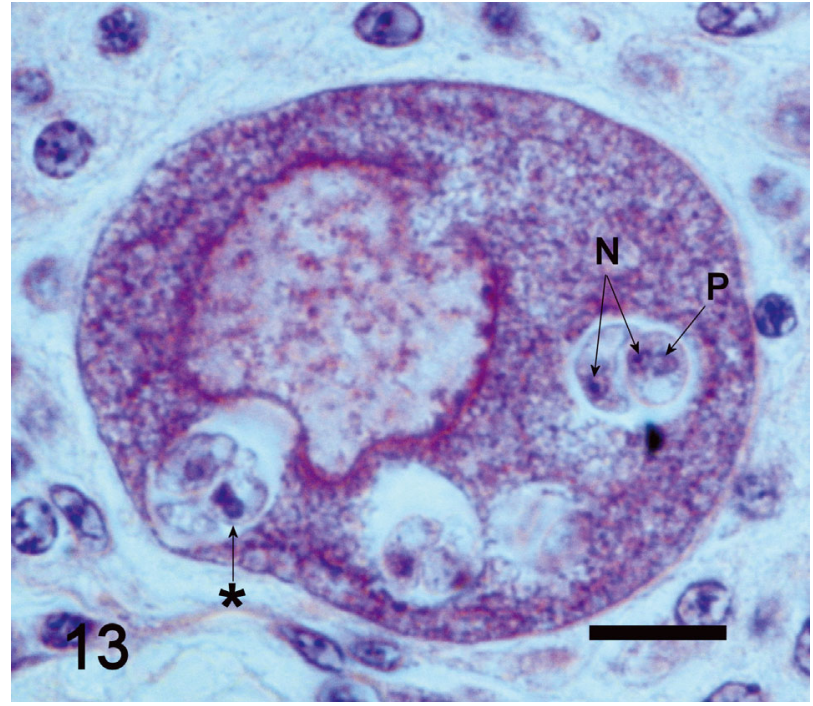

Fig. 13. Histological section (haematoxylin and eosin stain) of a parasitic amoeba in the gonad of a partially spawned female Crassostrea gigas from Read Island, BC, Canada. The nucleus $(\mathrm{N})$ and parasome $(\mathrm{P})$ are evident, and 1 specimen appears to be in late stages of division. Another pair of parasites (asterisk) has distorted the nucleus and cell wall of the oyster oocyte. The scale bar is $10 \mu \mathrm{m}$

required to assess the impact of UOPs on oysters in Brazil.

Paramoeba have been described as ectoparasites on the gills of fish (Dyková et al. 2000, Munday et al. 2001) and as endoparasites in several tissues of sea urchins (Jones et al. 1985, Feehan et al. 2013), lobsters (Mullen et al. 2004) and crabs (Johnson 1977). In these hosts, severe infections with paramoebae were often associated with host death. To date, no parasites in the genera Paramoeba or Janickina have been described from bivalve molluscs. Also, the length of amoeba trophozoites in fish (ranging from 16.3 to $37.5 \mu \mathrm{m}$; Dyková et al. 2000) and in sea urchin (ranging from 9 to $49 \mu \mathrm{m}$; Feehan et al. 2013) are greater than observed for the UOP described here.

To identify the amoeba species observed in the present study, additional research is necessary. For example, the UOP should be isolated in vitro and observed actively moving on a surface, because the number of pseudopods separates the genus Paramoeba from Janickina, which has only 1 active pseudopod. Also, transmission electron microscopy and molecular analysis including sequencing and in situ hybridization are recommended to identify additional details relating to morphological and molecular features and to reveal life cycle parameters, which are all necessary for a valid species description. Additional studies are required to examine whether a relationship exists between the sexual stage of the host and UOP prevalence and to evaluate UOP presence in other organs of the oysters.

Acknowledgements. We thank Raquel Aranguren Ruiz from the Spanish National Reference Laboratory for Molluscs Diseases, Spain, for training in parasite diagnosis. The Ministry of Fisheries and Aquaculture and the Santa Catarina State Foundation for Research Support (FAPESC), Brazil, provided support for the research. The National Council of Technological and Scientific Development, Brazil, supported the macro- and microscopic analysis (grant no. CNPq-558222/2008-0) and provided a grant (no. CNPq301072/2007-8) to M.L.M.; post-doctoral scholarship support to S.S. was provided by the Coordination for the Improvement of Higher Level Personnel (CAPES), Brazil. Catherine A. Thomson at Vancouver Island University (VIU) advised on the PCR methodology. Undergraduate students from the Federal University of Santa Catarina (UFSC), Brazil, and summer students from VIU assisted with the diagnostic procedure; the partnership between the VIU and the UFSC was facilitated by the World Fisheries Trust, Canada.

\section{LITERATURE CITED}

Audemard C, Reece KS, Burreson EM (2004) Real-time PCR for the detection and quantification of the protistan parasite Perkinsus marinus in environmental waters. Appl Environ Microbiol 70:6611-6618

Becker CD, Pauley GB (1968) An ovarian parasite (Protista Incertae Sedis) from the Pacific oyster, Crassostrea gigas. J Invertebr Pathol 12:425-437

Berthe FCJ, Le Roux F, Peyretaillade E, Peyret P, Rodriguez D, Gouy M, Vivares CP (2000) Phylogenetic analysis of the small subunit ribosomal RNA of Marteilia refringens validates the existence of Phylum Paramyxea (Desportes and Perkins, 1990). J Eukaryot Microbiol 47:288-293

Bower SM (2012) Synopsis of infectious diseases and parasites of commercially exploited shellfish: Steinhausia mytilovum (Mussel Egg Disease). DFO, Vancouver. Available at www.pac.dfo-mpo.gc.ca/science/species-especes/ shellfish-coquillages/diseasesmaladies/pages/medmu-eng. htm (accessed 29 July 2013)

Bower SM, Figueras AJ (1989) Infectious diseases of mussels, especially pertaining to mussel transplantation. World Aquac 20:89-93

> Bush AO, Lafferty KD, Lotz JM, Shostak AW (1997) Parasitology meets ecology on its own terms: Margolis et al. revisited. J Parasitol 83:575-583

Caraguel CG, O'Kelly CJ, Legendre P, Frasca SJ and others (2007) Microheterogeneity and coevolution: an examination of rDNA sequence characteristics in Neoparamoeba pemaquidensis and its prokinetoplastid endosymbiont. J Eukaryot Microbiol 54:418-426

Comps M, Park MS, Desportes I (1987) Fine structure of Marteilioides chungmuensis n.g. n.sp., parasite of the oocytes of the oyster Crassostrea gigas. Aquaculture 67: 264-265

Comtet T, Garcia C, Le Coguic Y, Joly JP (2003) Infection of the cockle Cerastoderma edule in the Baie des Veys (France) by the microsporidian parasite Steinhausia sp. Dis Aquat Org 57:135-139

Comtet T, Garcia C, Le Coguic Y, Joly JP (2004) First record 
of the microsporidian parasite Steinhausia mytilovum in Mytilus sp. (Bivalvia: Mytilidae) from France. Dis Aquat Org 58:261-264

Cunningham AA, Daszak P (1998) Extinction of a species of land snail due to infection with a microsporidian parasite. Conserv Biol 12:1139-1141

Da Silva PM, Magalhães ARM, Barracco MA (2012) Pathologies in commercial bivalve species from Santa Catarina State, southern Brazil. J Mar Biol Assoc UK 92:571-579

> Dyková I, Figueras A, Peric Z (2000) Neoparamoeba Page, 1987: light and electron microscopic observations on six strains of different origin. Dis Aquat Org 43:217-223

> Dyková I, Fiala I, Lom J, Lukeš J (2003) Perkinsiella amoebae-like endosymbionts of Neoparamoeba spp., relatives of the kinetoplastid Ichthyobodo. Eur J Protistol 39:37-52

> Dyková I, Fiala I, Pecková H (2008) Neoparamoeba spp. and their eukaryotic endosymbionts similar to Perkinsela amoebae (Hollande, 1980): coevolution demonstrated by SSU rRNA gene phylogenies. Eur J Protistol 44:269-277

> Feehan CJ, Johnson-Mackinnon J, Scheibling RE, LauzonGuay JS, Simpson AGB (2013) Validating the identity of Paramoeba invadens, the causative agent of recurrent mass mortality of sea urchins in Nova Scotia, Canada. Dis Aquat Org 103:209-227

> Fringuelli E, Gordon AW, Rodger H, Welsh MD, Graham DA (2012) Detection of Neoparamoeba perurans by duplex quantitative Taqman real-time PCR in formalin-fixed, paraffin-embedded Atlantic salmonid gill tissues. J Fish Dis 35:711-724

Green TJ, Brian JJ, Adlard RD, Barnes AC (2008) Parasites, pathological conditions and mortality in QX-resistant and wild-caught Sydney rock oysters, Saccostrea glomerata. Aquaculture 280:35-38

Hine PM, Thorne T (2000) A survey of some parasites and diseases of several species of bivalve mollusc in northern Western Australia. Dis Aquat Org 40:67-78

Hollande A (1980) Identification du parasome (Nebenkern) de Janickina pigmentifera a un symbionte (Perkinsiella amoebae nov. gen. - nov. sp.) apparenté aux flagellés Kinetoplastidiés. Protistologica 16:613-625

> Itoh N, Oda T, Yoshinaga T, Ogawa K (2003) DNA probes for detection of Marteilioides chungmuensis from the ovary of Pacific oyster Crassostrea gigas. Fish Pathol 38:163-169

Itoh N, Komiyama H, Ueki N, Ogawa K (2004a) Early developmental stages of a protozoan parasite, Marteilioides chungmuensis (Paramyxea), the causative agent of the ovary enlargement disease in the Pacific oyster, Crassostrea gigas. Int J Parasitol 34:1129-1135

Itoh N, Tun KL, Komiyama H, Ueki N, Ogawa K (2004b) An ovarian infection in the Iwagaki oyster, Crassostrea nippona, with the protozoan parasite Marteilioides chungmuensis. J Fish Dis 27:311-314

Ivachuk CS (2013) Efeito do manejo sobre a sobrevivência, ocorrência de patógenos e resposta imune da ostra Crassostrea gigas cultivada no Sul do Brasil. MSc thesis, Universidade Federal de Santa Catarina, Florianópolis

Johnson PT (1977) Paramoebiasis in the blue crab, Callinectes sapidus. J Invertebr Pathol 29:308-320

Jones GM, Hebda AJ, Scheibling RE, Miller RJ (1985) Histopathology of the disease causing mass mortality of sea urchins (Strongylocentrotus droebachiensis) in Nova Scotia. J Invertebr Pathol 45:260-271

Lee MK, Cho BY, Lee SJ, Kang JY, Jeong HD, Huh SH, Huh MD (2001) Histopathological lesions of Manila clam, Tapes philippinarum, from Hadong and Namhae coastal areas of Korea. Aquaculture 201:199-209

Matos E, Matos P, Azevedo C (2005) Observations on the intracytoplasmic microsporidian, Steinhausia mytilovum, a parasite of mussel (Mytella guyanensis) ovocytes from the Amazon River Estuary. J Morphol Sci 22:183-186

Mullen TE, Russell S, Tucker MT, Maratea JL and others (2004) Paramoebiasis associated with mass mortality of American lobster Homarus americanus in Long Island Sound, USA. J Aquat Anim Health 16:29-38

> Munday BL, Zilberg D, Findalay V (2001) Gill disease of marine fish caused by infection with Neoparamoeba pemaquidensis. J Fish Dis 24:497-507

Nascimento IA, Smith DH, Kern LF, Pereira SA (1986) Pathological findings in Crassostrea rhizophorae from Todos os Santos Bay, Bahia, Brazil. J Invertebr Pathol 47:340-349

OIE (World Organisation for Animal Health) (2013) Manual of diagnostic tests for aquatic animals. OIE, Paris. Available at www.oie.int/international-standard-setting/ aquatic-manual/access-online/ (accessed 29 July 2013)

Page FC (1983) Marine Gymnamoebae. Institute of Terrestrial Ecology, Cambridge. Available at http://nora.nerc. ac.uk/5144/1/Marine_gymnamoebae.pdf

Perkins FO (1996) The structure of Perkinsus marinus (Mackin, Owen and Collier, 1950) Levine, 1978 with comments on taxonomy and phylogeny of Perkinsus spp. J Shellfish Res 15:67-87

Pontinha VA (2009) Diagnóstico da saúde da ostra Crassostrea gigas (Thunberg, 1793) cultivada em Florianopólis/ SC. MSc thesis, Universidade Federal de Santa Catarina, Florianópolis

Rybakov AV, Kholodkovskaya EV (1987) Parasites and commensals of the mussel Mytilus galloprovincialis in the Northwest Black Sea. Biol Morya (Vladivostok) 2:22-29

Sabry R, Da Silva PM, Vasconcelos GTC, Pontinha AV, Magalhães ARM (2011) Pathological study of oysters Crassostrea gigas from culture and C. rhizophorae from natural stock of Santa Catarina Island, SC, Brazil. Aquaculture 320:43-50

Sabry RC, Gesteira TC, Magalhães ARM, Barracco MA and others (2013) Parasitological survey of mangrove oyster, Crassostrea rhizophorae, in the Pacoti River Estuary, Ceará State, Brazil. J Invertebr Pathol 112:24-32

Sagristà E, Bozzo MG, Bigas M, Poquet M, Durfort M (1998) Developmental cycle and ultrastructure of Steinhausia mytilovum, a microsporidian parasite of oocytes of the mussel, Mytilus galloprovincialis (Mollusca, Bivalvia). Eur J Protistol 34:58-68

> Shaw BL, Battle HI (1957) The gross and microscopic anatomy of the digestive tract of the oyster Crassostrea virginica (Gmelin). Can J Zool 35:325-347

> Tanifuji G, Kim E, Onodera NT, Gibeault R and others (2011) Genomic characterization of Neoparamoeba pemaquidensis (Amoebozoa) and its kinetoplastid endosymbiont. Eukaryot Cell 10:1143-1146

- Villalba A, Mourelle SG, Carballal MJ, López C (1997) Symbionts and diseases of farmed mussels Mytilus galloprovincialis throughout the culture process in the Rías of Galicia (NW Spain). Dis Aquat Org 31:127-139

Weibel ER, Kistler GS, Scherle WF (1966) Practical stereological methods for morphometric cytology. J Cell Biol 30:23-38

> Young ND, Dyková I, Nowak BF, Morrison RN (2008) Development of a diagnostic PCR to detect Neoparamoeba perurans, agent of amoebic gill disease. J Fish Dis 31: 285-295 